\title{
PENGEMBANGAN MODEL PAIR CHECK UNTUK MENGHINDARI MIND IN CHAOS SISWA KELAS X TERHADAP PEMBELAJARAN MATEMATIKA
}

\author{
Nenden Suciyati Sartika ${ }^{1)^{*}}$, Susti Rahmah Yulita $\mathbf{S}^{2)}$ \\ ${ }^{1,2)}$ Pendidikan Matematika, Fakultas Keguruan dan Ilmu Pendidikan, \\ UniversitasMathla'ul Anwar, Pandeglang, Banten, 42273 \\ *nendensuciyatisartika@gmail.com
}

\begin{abstract}
Abstrak
Tujuan penelitian ini adalah untuk mengembangkan model pembelajaran Pair Check yaitu pembelajaran kooperatif yang merupakan salah satu alternatif yang dapat digunakan dalam pembelajaran matematika, selain untuk meningkatkan motivasi dan hasil belajar, mengoptimalkan pembagian kerja dalam kelompoknya, model ini dikembangkan untuk menghindari terjadinya mind in chaos, suatu kesan negatif yang dibiarkan terjadi sejak mereka masih kecil, yang pada akhirnya hingga dewasa kesan negatif tersebut, yang menyatakan bahwa matematika itu sulit dan menakutkan tetap menetap pada siswa. Metode yang digunakan dalam penelitian ini adalah $R \& D$ (Research and Development). Hasil penelitian adalah model Pair Check untuk menghindari Mind In Chaos pada pembelajaran matematika sehingga memberikan pengalaman dan kesan positif siswa terhadap matematika. Desain dan implementasi dari penelitian ini diharapkan menjadi salah satu referensi perkuliahan pada program studi Pendidikan Matematika di Fakultas Keguruan dan Ilmu Pengetahuan, Universitas Mathla’ul Anwar Banten.
\end{abstract}

Kata Kunci: Research and Development, Mind in Chaos, Pair Check

\section{PENDAHULUAN}

Merujuk pada penelitian yang dilakukan oleh Maman Fathurohman (2009) mengenai penggunaan Board Game untuk menghindari mind in chaos di kabupaten serang yang pada awalnya sebagian besar siswa menganggap matematika adalah pelajaran yang sulit bahkan menakutkan. Demikian itu terjadi karena adanya rasa takut akan matematika yang mendekam dalam fikiran. Rasa takut ini terjadi dikarenakan adanya Mind in
Chaos (Fathurohman, 2009), yaitu suatu kesan negatif yang dibiarkan terjadi sejak mereka masih kecil, yang pada akhirnya hingga dewasa kesan negatif tersebut, yang menyatakan bahwa matematika itu sulit dan menakutkan tetap tertanam. Salah satu saran yang diajukan untuk mengatasinya adalah melalui permainan dan pengalaman menarik lain yang terkait dengan matematika.

Menurut Ausubel, jika seorang anak berkeinginan untuk mengingat sesuatu 
tanpa mengaitkan hal yang satu dengan hal yang lain maka baik proses maupun hasil pembelajarannya dapat dinyatakan sebagai hafalan dan tidak akan bermakna sama sekali baginya. Oleh sebab itu perlu dirancang dan dikembangkan suatu perangkat pembelajaran. (Nurhayati, 2017).

Pada penelitian ini peneliti mencoba mengembangkan model pembelajaran pair check yaitu pembelajaran kooperatif yang merupakan salah satu alternatif yang dapat digunakan dalam pembelajaran matematika, selain untuk meningkatkan motivasi dan hasil belajar, mengoptimalkan pembagian kerja dalam kelompoknya, model ini dikembangkan untuk menghindari terjadinya mind in chaos suatu kesan negatif yang dibiarkan terjadi sejak mereka masih kecil, yang pada akhirnya hingga dewasa kesan negatif tersebut, yang menyatakan bahwa matematika itu sulit dan menakutkan tetap menetap pada siswa.karena terlihat dari langkah-langkah pembelajaran yang mencoba melibatkan siswa secara aktif melalui pengecekan atau peninjauan terhadap pasangan kelompoknya dan pada akhirnya siswa merasa pembelajaran matematika tidak menakutkan dan sebaliknya menyenangkan. Dan berdasarkan pertimbangan tersebut model pembelajaran pair check diduga dapat menghindari mind in chaos siswa SMAN 10 Pandeglang.

Langkah-langkah pembelajaran dalam Pair Check adalah sebagai berikut:

\section{Langkah 1}

\section{Bekerja berapasangan}

Siswa dibagi menjadi

beberapa

kelompok. Kelompok - kelompok tersebut terbagi menjadi pasangan-pasangan yang disebut tim berpasangan.

\section{Langkah 2 \\ Pelatih Mengecek.}

Pada langkah ini pelatih memeriksa pekerjaan pasangannya (patner).

\section{Langkah 3}

\section{Pelatih member reward}

Apabila partner menjawab benar, maka pelatih memberi kupon agar suasana lebih menarik.

\section{Langkah 4}

\section{Bertukar Peran}

Setelah selesai mengecek, seluruh pasangan bertukar peran, dan mengulangi langkah 1-3.

\section{Langkah 5}

\section{Pasangan Mengecek (Pair Check)}

Seluruh pasangan tim kembali bersama dan membandingkan jawaban - jawaban mereka untuk melihat apakah mereka sepakat.

\section{Langkah 6 \\ Penegasan Guru}

Guru mengarahkan jawaban atau ide sesuai konsep.

\section{Langkah 7 \\ Perayaan Kelompok}

Bila semua anggota kelompok sepakat dengan jawabannya, maka mereka saling bersalaman atau dengan cara bersorak tanda setuju, dengan kata-kata tertentu yang membuat mereka semangat. Selain itu, guru memberikan penghargaan kepada kelompok yang jawabannya benar.

Sintak dari Pair Check adalah sajian informasi kompetensi, mendemontrasikan pengetahuan dan keterampilan prosedural, membimbing pelatihan penerapan, Pair Check siswa berkelompok berpasangan sebangku, salah seorang menyajikan 
persoalan dan temannya mengerjakan, pengecekan kebenaran jawaban, bertukar peran, penyimpulan dan evaluasi, refleksi (Suyatno, 2009).

Menurut Piaget pengertian dan pemahaman seseorang itu mengalami perkembangan dari lahir sampai menjadi dewasa. Piaget meyakini bahwa perkembangan kognitif seseorang terjadi dalam empat tahapan. Empat tahap yang dimaksudkan dari teori perkembangan kognitif Piaget, yaitu Tahap sensori motor, Tahap preoperasi, Tahap operasi kongkrit, dan Tahap operasi formal. (Ruseffendi, 2006).

Dalam upaya mengarahkan proses pendidikan yang sesuai, maka diperlukan suatu model pembelajaran yang sesuai pula. Oleh karena itu perlu tindakan mengembangkan model pembelajaran yang bertujuan untuk menghindari Mind in Chaos terhadap pembelajaran. Beberapa indikator tentang terjadinya mind in chaos diantaranya (1) pembelajaran matematika yang tidak menyenang-kan, (2) siswa berpandangan bahwa matematika tidak kreatif, (3) pandangan bahwa matematika abstrak dan tidak terkait dengan realitas, dan (4) matematika merupakan tes atau ujian semata.

\section{METODE PENELITIAN}

Metode yang digunakan dalam penelitian ini adalah R \& D (Research and Development) yaitu mengembangkan model Pair Check untuk menghindari Mind In Chaos pada pembelajaran matematika. Model penelitian pengembangan yang dipilih dalam penelitian ini adalah melalui rangkaian langkah-langkah penelitian dan pengembangan yang dilakukan secara siklis dan pada setiap langkah yang dilakukan selalu mengacu pada hasil langkah sebelumnya, hingga pada akhirnya diperoleh suatu produk pendidikan yang baru.

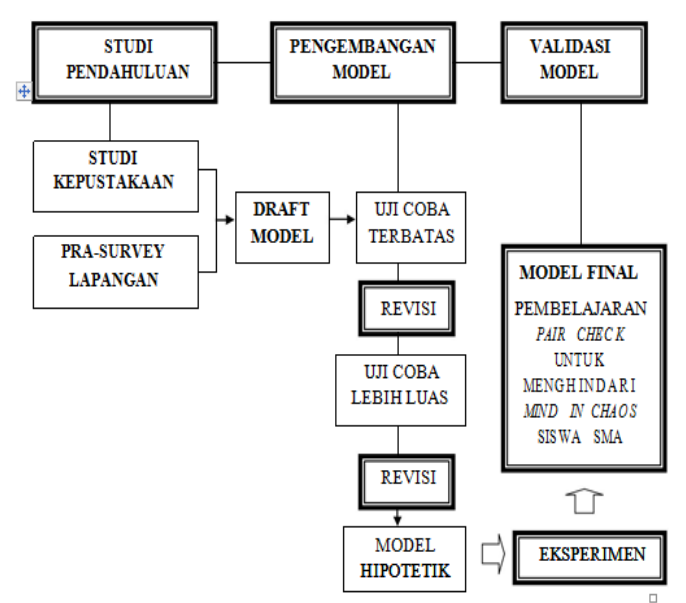

Gambar 1. Alur Penelitian dan Pengembangan Model

Tahapan-tahapan dalam tahap pelaksanaan penelitian ini, yaitu (1) Studi Pendahuluan (pra-survey),

Pengembangan Model, dan (3) Validasi Model. Penelitian ini menggunakan pendekatan analisis kualitatif dan kuantitatif, karena pada dasarnya data-data yang diperoleh juga berupa data kualitatif dan kuantitatif. Analisis data yang digunakan dalam penelitian ini meliputi: (1) analisis data pada tahap studi pendahuluan, (2) analisis data pada tahap pengembangan model, dan (3) analisis data pada tahap validasi. Validasi yang dimaksud adalah untuk mengukur kevaliditasan Buku Ajar pada pokok bahasan Trigonometriyang menggunakan media Trigamaster.

Penelitian ini dilaksanakan di SMAN 10 Pandeglang Tahun Ajaran 2017/2018, untuk subyek penelitian dipilih secara purposive sampling yaitu kelas $\mathrm{X}$ IPA 2 dan penelitian ini dimulai dari dari bulan Oktober 2017 sampai September 2018. 


\section{HASIL DAN PEMBAHASAN}

Penelitian ini mengkaji tentang hasil studi pendahuluan yang dilakukan oleh tim peneliti yang mendapati bahwa banyak peserta didik yang kurang memahami bahkan merasa takut dengan matematika, bagaimana matematika itu terjadi dan bagaimana menyelesaikan permasalahan matematika dengan baik berdasarkan analisis yang dibutuhkan, oleh karena itu dibutuhkan sebuah model pembelajaran yang salah satunya adalah model pembelajaran Pair Check.

Buku Ajar yang dihasilkan, divalidasi dengan menggunakan teknik triangulasi, yaitu pengecekan data dari berbagai sumber dengan berbagai cara dan waktu, serta proses menggunakan lebih dari satu sumber untuk mengkonfirmasi informasi. Setelah itu dilakukan pengecekan dan pembanding sebagai dasar untuk merevisi perangkat pembelajaran yang dikembangkan.

Kevaliditasan Buku Ajar pada pembelajaran fokus pada tiga karakteristik, yaitu content, konstruk dan bahasa, sebelumnya peneliti meminta pendapat dari beberapa pakar dan teman sejawat yang sudah berpengalaman dalam pendidikan matematika terutama dibidang pembelajaran, dan untuk menghindari mind in chaos, materi pokok bahasan trigonometri, dan orang yang bepengalaman dalam pendidikan bahasa indonesia yang juga mengerti masalah matematika yang dapat berkomentar masalah tata kalimat yang ada pada Buku Ajar.

Pada penelitian ini, observasi dilakukan saat proses pembelajaran berlangsung dengan model pembelajaran pair check yang dilakukan dalam 6 kali pertemuan, dengan jumlah siswa 28 orang masing kelompok berjumlah 4 orang, dan setiap pertemuan menggunakan Buku Ajar yang dilengkapi dengan media trigamaster, Siswa diajak bagaimana menemukan sudut yang dihitung melalui Trigamaster dan setiap kelompok diberikan media yang sama sehingga pada saat diberikan latihan mandiri dan mengecek secara berpasangan siswa dapat menjawab dan mengetahui kekeliruan yang dilakukan sendiri ataupun teman pasangannya.

Lembar observasi terdiri dari 3 aspek, yaitu: model, penilaian diri sendiri, dan kerjasama yang menilai 3 aspek tersebut berjumlah 4 orang observer (termasuk peneliti). Rata-rata hasil dari 7 kelompok masing-masing saat menggunakan Buku ajar sedangkan ratarata hasil observasi disajikan pada tabel berikut.

Tabel 1. Persentase Rata-Rata Observasi Aktivitas Pembelajaran Melalui Buku Ajar

\begin{tabular}{lc}
\hline \multicolumn{1}{c}{ Aspek } & Rata-Rata \\
\hline Model pair check & 83 \\
\hline Penilaian diri sendiri & 85 \\
\hline Kerjasama & 75 \\
\hline
\end{tabular}

Setiap aspek yang ada disesuaikan pada ketercapaian proses pembelajaran dalam menghindari mind in chaos yang terjadi pada siswa, pada aspek model terlihat bahwa siswa sudah bisa mengidentifikasi unsur-unsur yang penting, sedangkan pemahaman siswa terhadap masalah masih kurang karena siswa salah dalam menginterpretasikan bahasa sehari-hari kedalam bahasa matematika, sehingga siswa mengalami kesalahan dalam membangun model. Pada aspek penilaian siswa sudah dapat menguji solusi yang sudah mereka dapatkan, namun masih ada siswa yang belum bisa menilai atau mengetahui bahwa solusi yang 
mereka dapatkan termasuk benar atau salah, ini terlihat pada saat diskusi ada siswa yang mengatakan jawabannya benar, padahal dalam penghitungan mereka mengalami kekeliruan misalnya ketika dihitung nilai suatu sudut itu adalah $35^{\circ}$ dan ketika menggunakan media trigamaster ternyata nilai besar sudut tersebut adalah $30^{\circ}$ dalam hal ini aspek kerjasama siswa sudah dapat mempresentasikan solusi yang mereka dapatkan, namun siswa masih kurang dalam berdiskusi dengan kelompok lainnya berdasarkan argumen dan solusi masingmasing. Sehingga, dari hasil observasi tersebut ketiga aspek aktivitas pembelajaran model pair check baru mencapai 75 atau secara rata-rata baru mencapai kategori cukup.

Pembelajaran merupakan upaya untuk membelajarkan peserta didik agar dapat mengembangkan kemampuannya secara optimal.Pengembangan yang diorientasikan dalam pembelajaran adalah pengembangan kemampuan berpikir, bernalar, dan termasuk juga bagaimana peserta didik tersebut dapat memecahkan masalah yang dihadapinya dalam kehidupan sehari-hari. Pembelajaran pada masa sekarang ini lebih berorientasi kepada aktivitas peserta didik yang lebih aktif dan dominan terlibat dalam proses pembelajaran sehingga mereka akan mendapatkan pengalaman yang dapat mengembangkan kemampuan berpikirnya dengan lebih baik.

Dengan mengamati kegiatan pembelajaran didalam kelas, interaksi antara guru dengan peserta didik tejalin cukup baik. Terutama ketika awal kegiatan pembelajaran dimulai, namun terdapat beberapa peserta didik yang kurang bersemangat pada awal pembelajaran dan kurang menyimak atau memperhatikan ketika guru menjelaskan materi pembelajaran. Ketika guru membahas materi pembelajaran sebagian peserta didik aktif dalam bertanya bahkan ada yang bersikap apatis terhadap materi yang kurang dipahami oleh peserta didik didalam kelas. Salah satu upaya yang digunakan menghindari mind in chaos siswa SMAN 10 Pandeglang yaitu dengan menerapkan Model Pembelajaran Pair Check dimana model yang diterapkan dalam pembelajaran di yaitu pembelajaran yang melibatkan siswa untuk memecahkan masalah secara berpasangan untuk saling mengecek kesalahan dan kekeliruan serta ketepatan selain itu mengevaluasi secara bersama.

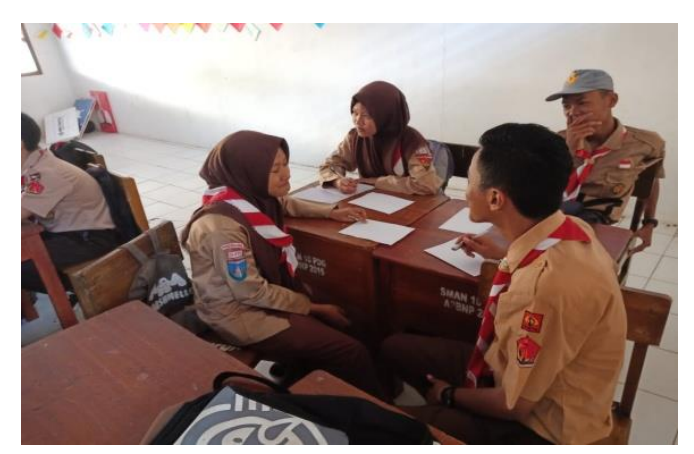

Gambar 2. Langkah Pada Saat Siswa Melakukan Pasangan Mengecek (Pair Check)

Pada uji coba tahap pertama dilakukan di kelas dengan peserta didik berjumlah 28 orang. Seluruh peserta didik dikelas ini berdasarkan hasil wawancara yang dilakukan oleh peneliti selama proses pembelajaran baik sesudah pembelajaran maupun sebelum pembelajaran selama jangka waktu empat minggu mandapat kesan yang sangat baik dimana peserta didik dikelas IPA 2 merasa senang dan merasa tertantang dengan proses pembelajaran yang mengedepankan peserta didik agar berfikir kritis, kreatif dan dapat menyelesaikan masalah. Peserta didik menjadi tertantang ketika 
diperlakukan dewasa dan bertanggung jawab dengan tugas-tugas yang diberikan oleh guru. Selama proses pembelajaran berlangsung guru tidak hanya mengajak peserta didik menyelesaikan masalahnya saja tetapi juga mengajak peserta didik agar dapat memahami mengapa dan bagaimana melakukannya dan mengimplementasikan pembelajaran matematika kedalam kehidupan seharihari. Hasil evaluasi dapat dilihat bahwa setiap pertemuan peserta didik menunjukan perbaikan-perbaikan sikap dalam belajar baik belajar mandiri atau individu maupun kerjasama atau kelompok dengan menggunakan pembelajaran pair check.

Tabel 2. Hasil Uji Coba Penerapan Model Pair Check untuk Menghindari Mind in Chaos

\begin{tabular}{lllll}
\hline Penilaian & M 1 & M 2 & M 3 & M 4 \\
\hline Hasil & 1.60 & 2.73 & 2.79 & 2.85 \\
\hline Kemajuan & 1.70 & 2.75 & 2.89 & 2.90 \\
\hline Model & 2.31 & 2.75 & 2.80 & 2.85 \\
\hline Kerjasama & 2.50 & 2.60 & 2.65 & 2.80 \\
\hline
\end{tabular}

Aktivitas pembelajaran melalui pair check dapat menghindari mind in chaos siswa terhadap matematika, hal ini terlihat ketika siswa merasa bahwa matematika bukan pelajaran yang menakutkan dan dari beberapa kuesioner yang diberikan serta direspon siswa menyatakan bahwa model atau cara pembelajaran di kelas dapat mempengaruhi tingkat motivasi belajar siswa. Dalam model pair check siswa diajak bagaimana untuk mengeluarkan ide dan tanggapan sesama teman dengan bekerjasama dan hal ini menjadi jalan untuk lebih terbukanya wawasan, tidak terbatasnya jarak, dan merasa nyaman ketika menyampaikan ketidaktahuan atau ketidakpahaman terhadap suatu bahasan. Dampak dari terjadinya saling mengkoreksi, menanggapi bahkan berdiskusi membuat matematika tidak lagi menjadi pembelajaran yang monoton yaitu penyampaian hanya dikuasai oleh seorang guru dan siswa mendegarkan serta bersiap untuk diberikan latihan soal sebelum mereka memahami dengan baik apa yang disampaikan oleh guru.

\section{SIMPULAN}

Berdasarkan hasil penelitian, dapat disimpulkan sebagai berikut:

1. Buku Ajar danLembar Kerja Siswa (LKS) pada materi trogonometri dikategorikan valid dan praktis. Buku Ajar dikatakan valid berdasarkan penilaian para validator, dan sudah melalui proses validasi oleh pakar berdasarkan content, konstruk, dan bahasa. Sehingga dalam penggunaannya di pembelajaran dengan model pair check dapat menghindari mind in chaos siswa terhadap matematika.

2. Pengembangan Model pembelajaran pair check merupakan salah satu cara untuk membantu siswa yang pasif dalam kegiatan kelompok, mereka melakukan kerjasama secara berpasangan dan menerapkan susunan pengecekan berpasangan sehingga pelaksanaan pembelajaran berlangsung menyenangkan dan aktif karena adanya proses diskusi dan mengkoreksi.

3. Mind in chaos siswa selama pembelajaran terlihat berkurang bahkan ada yang menghilang karena siswa secara aktif bersama teman pasangan dalam satu kelompok merasa bahwa matematika bukan lagi menjadi pelajaran yang ditakuti bahkan pembelajaran berlangsung secara menyenangkan. 


\section{UCAPAN TERIMA KASIH}

Terimakasih kepada DRPM Kemenristek DIKTI yang telah mendanai Hibah Penelitian Skim Penelitian Dosen Pemula untuk Tahun Anggaran 2018

\section{DAFTAR PUSTAKA}

Fathurohman, dkk. 2008. "Mengembangkan Board Game Labirin Matematika Bagi Siswa Rendah Guna Menghindari Mind In Chaos Terhadap Matematika". Makalah Dalam: Seminar Nasional Penelitian, Pendidikan dan Penerapan MIPA, 16 Mei 2009.

Huda, M. 2014. Model-Model Pengajaran dan Pembelajaran Isu-Isu Metodis dan Paradigmatis. Yogyakarta: Pustaka Pelajar.

Nurhayati, Nunu. 2017. "Pengembangan Bahan Ajar Trigonometri Berbasis Kontekstual melalui Metode Guide Discovery untuk Meningkatkan Pemahaman Konsep Mahasiswa". FIBONACCI: Jurnal Pendidikan Matematika dan Matematika. Vol. 3 (1), pp: 31-44.

Rusefendi.2006. Pengantar Kepada Membantu Guru Mengembangkan Kompetensinya dalam Pengajaran Matematika. Bandung: Tarsito.

Suyatno. 2009. Menjelajah Pembelajaran Inovatif. Sidoarjo: Masmedia Buana Pustaka. 
FIBONACCI : Jurnal Pendidikan Matematika dan Matematika

Volume 5 No. 2 Bulan Desember Tahun 2019

\section{4}

